\title{
BASIC DIRECTIONS OF CONTEMPORARY POSTAL SERVICES MARKETS TRANSFORMATION
}

\section{ROMAN CZAPLEWSKI}

University of Szczecin, Faculty of Management and Economics of Services, POLAND

e-mail: roman.czaplewski@wzieu.pl

\begin{tabular}{l|l}
$\begin{array}{l}\text { RECEIVED } \\
\text { ACCEPTED }\end{array}$ & $\begin{array}{l}10 \text { December } 2018 \\
28 \text { December } 2018\end{array}$ \\
JEL & Le7, 014 \\
KEYSSIFICATION & postal services market, digitalization, Internet, innovative information and communication services \\
ABSTRACT & $\begin{array}{l}\text { On modern postal markets the demand for traditional services is falling and it is clearly visible especially on the } \\
\text { letters market. This forces postal operators to undertake the provision of innovative information and communi- } \\
\text { cation services. Entering the area of these services, postal operators start by offering so-called hybrid services, } \\
\text { e-deliveries and engaging in e-commerce. }\end{array}$
\end{tabular}

\section{Introduction}

Modern postal services markets (PSM) are subject to significant transformations, which can be divided into changes related to:

- liberalization and deregulation of PSM,

- increasing impact digitization and the Internet on the PSM. 
The transformations related to the introduction of liberalization and deregulation as well as the consequences of these processes have been widely described in the scientific literature. The literature proves that liberalization and deregulation processes carried out in the area of PSM lead in particular to the elimination of monopoly and the introduction of competition in this market (Buko, 2009, pp. 89-105; Dehnen, 1990; Drab-Kurowska, 2007, pp. 237242; Sondej, 2012, pp. 134-141).

Current changes in the PSM area are mainly connected with the development of digitization and the Internet. The aim of the article is to try to identify the main reasons for the growing interest of postal operators in digitization and in the Internet as well as the basic directions of the impact of digitization and Internet on the PSM and to show the impact of digitalization and the Internet on the market activities of postal operators.

To accomplish the assumed goal, the author used:

- critical analysis of scientific literature on the subject PSM,

- available empirical data showing changes occurring in contemporary PSM,

- observation of the behavior of postal operators involved in the use of digitization and the internet.

\section{Basic reasons for the growing role of digitization and the Internet in the PSM area}

The interest of postal operators in the increasing use of digitalization and the Internet is largely due to the fact that the market for traditional letters, which played a fundamental role in the activities of postal operators, is not very promising. This is evidenced by the data presented in Figure 1, showing the decrease in the number of letters in selected countries in the period covering the years 2007-2012.

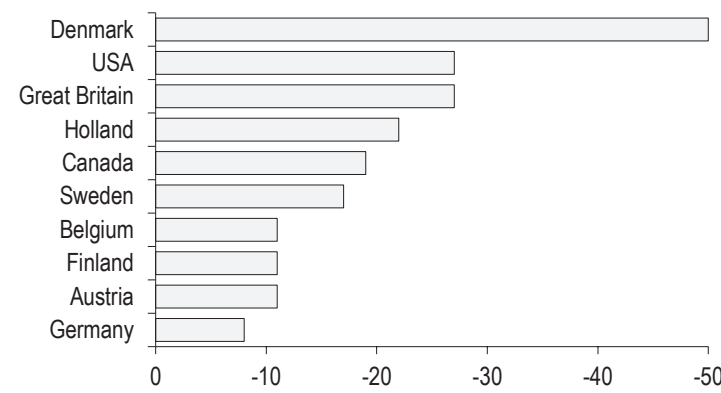

Figure 1. Decrease in the number of letters in selected countries in the years 2007-2012 (\% of the number of letters sent) Source: Statista (2014), after: Die Revolution im... (2017), p. 2.

The falling demand for traditional letters means that the service of parcels and express parcels is becoming increasingly important in the activity of postal operators. Information on the percentage of large EU postal operators measured in terms of turnover in the area of the letters and parcels market is presented in Figure 2. 


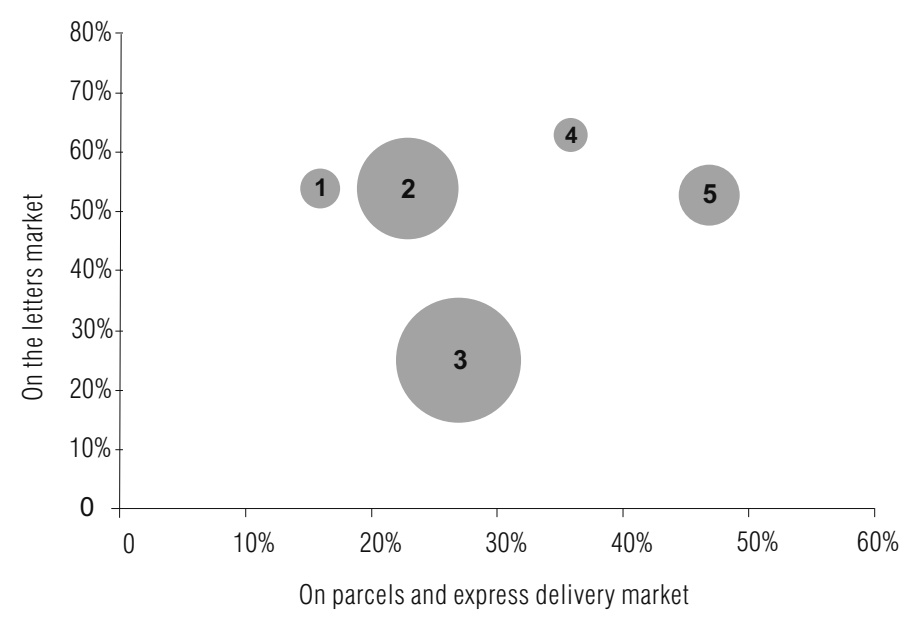

Explanatory notes: 1 - Dutch postal service (PostNL) - 4.3 billion euro, 2 - French postal service (La Poste) - 22.0 billion euro, 3 - German post (Deutsche Post) - 56.0 billion euro, 4 - Austrian postal office (Österreichische Post) - 2.4 billion euro, 5 - British postal service (Royal Mail) - 11.0 billion euro.

Figure 2. Percentage shares of selected significant incumbent operators in the letters market as well as the parcel and express parcel market

Source: Monitoring Brief...(2014), p. 21.

The emerging new conditions of the PSM characterized by a permanent and growing decline in demand for traditional letter shipments, formerly the main source of revenue for postal operators, force these operators to change their existing business models. ${ }^{1}$ Looking for a business model adapted to the new conditions of the PSM, postal operators begin to focus on two areas of activity. On one hand, they continue to provide traditional services, i.e.:

- delivering letters, advertising and press,

- delivering parcels and courier shipments,

- retail operations carried out at post offices, including, among others, provision of financial services and conducting of small trade, e.g. sale of stamps, stationery.

On the other hand, they expand their traditional activities by:

- hybrid services, e.g. letters sent electronically between post offices, printed and packaged in traditional envelopes and delivered to the recipient in this form,

- services related to the operation of Internet-based activities, e.g. undertaking the delivery of shipments ordered electronically (e-commerce), as well as developing the so-called. e-deliveries (as a modern form replacing traditional registered items delivered with confirmation of receipt).

\footnotetext{
${ }^{1}$ Detailed information on the essence of a business model and principles of its shaping is included in the study of M. Czaplewski
} (2015). 


\section{The main areas of digitization and Internet use on SPM}

The growing interest of postal operators in the provision of so-called hybrid services, developing the socalled e-deliveries, constituting a modern form of shipments replacing traditional registered mail as well as growing interest in e-commerce, including in particular the service of delivery of e-commerce orders, results mainly from the real potential possessed by postal operators and their skills in organizing packages and letters shipments.

The material potential possessed by postal operators creates in particular a relatively modern and welldeveloped distribution system that allows them to adapt to the growing expectations of customers regarding the speed of shipments delivery. The availability of a large number of well-located outlets by these operators favors the fulfillment of the accessibility requirement important for customers. Having such advantages, incumbent operators are natural partners for companies running e-commerce and seeking suppliers of goods sold by them.

To make the best use of this potential to offer innovative information and communication services, postal operators strive to further modernize their infrastructure networks, including automatic sorting centers. The modern distribution centers built by incumbents allow not only to improve transport and logistics processes, but also enable these operators to transform into sellers of a wide range of innovative services, including the following ones (Die Post..., 2008, p. 19):

- printing letters and enveloping them (after providing the customer with a pattern of content and addresses),

- printing advertising mails, insurance policies and guaranteeing their delivery,

- scanning of shipments.

Having such distribution centers creates good conditions for postal operators to engage in the growing area of hybrid services, ${ }^{2}$ the segment of e-mail services ${ }^{3}$ and in the rising e-commerce, promising further dynamic development.

The dynamic development of e-commerce and the assumed prospects for its further development make postal operators pay special attention. For postal operators, the benefits of e-commerce development are manifested in two basic ways:

- growing demand for parcels,

- limiting the falling demand for letters, as a result of their increasing use for delivery of small goods ordered electronically by clients.

The importance of developing e-commerce for the results of postal operators' activities causes their strong involvement in improving the quality of services connected to the e-commerce process. ${ }^{4}$ In the case of postal

\footnotetext{
${ }^{2}$ An example of such services are letters sent by electronic mail between post offices, then packaged in traditional envelopes and delivered to the recipient in this form. There is a growing demand for these services reported by the Small and Medium Enterprises (Niederpruem, 2018).

${ }^{3}$ The development of e-mail services results not only from the convenience of using this modern information and communication service. An important factor supporting the development of this service is also the central regulations in force in some countries, which assume the priority treatment of electronic communication in the contacts of citizens with governmental administration. Five European countries have already applied such a solution: Denmark, Estonia, France, Netherlands and Sweden (Jung, 2018). This forces postal operators who want to maintain an important position in the provision of innovative information and communication services, to develop and implement solutions that will make it easier for clients to contact the state offices electronically.

${ }^{4}$ Information on the methods used to improve the organization of e-commerce, especially the delivery phase in the e-commerce process is presented by M. Czaplewski (2016).
} 
operators, this is manifested first of all by the common introduction of the following solutions (Bender, Hildebrand, 2018):

- informing recipients using SMS about the planned delivery date,

- providing the recipient with the possibility of continuous tracking of the shipment's location,

- providing the recipient with the possibility of choosing a specific delivery method, e.g. to the house, to a specific point of sale,

- providing the recipient with a choice of a specific time interval of delivery of the parcel.

\section{Basic activities of Polish Post using digitalisation and the Internet}

The development of various forms of internet-based activities, especially e-commerce, ${ }^{5}$ coupled with a drop in demand for traditional postal services, means that postal operators invest increasingly in building a strong position in the growing new market segment. The scale of these investments depends on resources, and these have, in particular, the so-called incumbent postal operators. This is indicated, among others, by the situation on the Polish PSM.

The main operator of this market - Poczta Polska - has created a 24-hour monitoring center, coordinating the work of postal logistics to ensure timely delivery of all shipments. Poczta Polska also increased the number of collection points for parcels by signing contracts with the convenience stores chains like Żabka and Freshmarket as well as with Ruch and Orlen stations, thanks to which it is possible to collect courier parcels sent via Poczta Polska. The adopted line of action is the response of this operator to the increasingly popular by customers Click $\&$ Collect solution, allowing online buyers to decide where to pick up the purchased goods.

Dynamically growing e-commerce requires not only an attractive organization of the delivery stage, but also safe and easy payment. Among other things, the Polish Post has equipped all couriers with payment terminals enabling card payments and so-called Blik payments. In September 2017, it established the digital brand of the Bank Pocztowy-Envelo Bank. This bank proposes, among others, the so-called Envelobonus, allowing the reimbursement of some money to online buyers, who choose Pocztex courier as a delivery form (Kuraszkiewicz, 2017). Another example of the emphasis placed by Poczta Polska on developing digital operations is the establishment of Poczta Polska Usługi Cyfrowe - PPUC Envelo. Thanks to the Envelo.pl platform, it is, among others, possible to (www. envelo.pl, 2018):

- buy electronically a postage stamp with your own graphics,

- send a letter or card, receiving a scan of your own shipment (so-called Neolist, Neokartka),

- set up an Envelo account.

It should also be emphasized that in August 2016 an agreement was signed between Envelo and Poczta Polska on one side, and the Ministry of Digitization and the Ministry of Infrastructure and Construction, on the other side, indicating the need to integrate the Envelo digital platform with the state systems and develop principles for the provision of e-delivery services. ${ }^{6}$ Moreover, Poczta Polska plans an investment project in remodeling of its

\footnotetext{
${ }^{5}$ More on the development of e-commerce see (Skorupska, 2017; Czaplewski, 2018, pp. 161-162).

${ }^{6}$ It is estimated that in Poland, the introduction of e-deliveries instead of traditional registered mail with confirmation of receipt will save about PLN 104 million on an annual basis (Envelo lider..., 2017).
} 
logistics network, assuming the construction of a logistics hub in the vicinity of the Central Communication Port to be established in Poland (Poczta postawi..., 2017).

The presented information indicate that the main operator of the Polish PSM is trying to use:

- new technological solutions (digitization, Internet, special self-service boxes for sending and receiving parcels by customers),

- new organizational solutions (delivery of parcels to the customer's home, to various commercial outlets, dispatching of payment terminals by couriers).

To develop these solutions it uses the potential of:

- own internal units (e.g. IT department, logistics division, some Post Bank structures),

- external units with which Poczta Polska cooperates (e.g. Post Bank, Orlen)

This means moving away from previous solutions using only their own internal units and supporting themselves with the services of specialized external units. This makes it easier for Poczta Polska to master new competences needed to provide innovative information and communication services.

\section{Conclusions}

The emphasis on the provision of innovative information and communication services by postal operators is primarily due to the decreasing demand for traditional letters. This emphasis is strengthened by the introduction, by some countries, regulations requiring priority treatment of electronic communication between citizens and governmental administration.

Taking into account the possessed competences, postal operators interested in developing electronic communication, firstly engage in the implementation of the so-called hybrid mail, e-mail and e-commerce services. Postal operators interested in the development of these areas of activity increasingly take them into account within the undertaken investments, prioritizing investments necessary for the provision of innovative information and communication services.

In the conditions of falling and expected further decline in demand for traditional letters, the growing involvement of postal operators in the provision of innovative information and communication services should be considered fully justified.

\section{References}

Bender, Ch.M., Hildebrand, A. (2018). Auswirkungen der Digitalisierung auf die Zustelllogistik. WIK Diskussionsbeitraege, 433, Oktober. Buko, J. (2009). Powszechne usługi pocztowe w Polsce. Stan obecny i koncepcja zmian. Szczecin: Wydawnictwo Naukowe Uniwersytetu Szczecińskiego.

Czaplewski, M. (2015). Modele biznesowe bankowości mobilnej. In: M. Cicharska (ed.), Bankowość mobilna (pp. 28-59). Warszawa Texter.

Czaplewski, M. (2016). E-commerce in Poland and Denmark - comparative analysis and development trends. The Business \& Management Review, 7 (5), 399-403.

Czaplewski, M. (2018). The use of e-commerce in the promotion and sale of hand made products. Management, 22 (1), $154-162$.

Dehnen, A. (1990). Kommunikationsmärkte im Monopol oder im Wettbewerb? ZPT, 6.

Die Post hat Zukunft (2008). in: Die Zukunft ist Gelb. Geschäftsbericht, Österreichische Post AG.

Die Revolution im Briefmarkt. Postmarkt im Umbruch (2017). Retrieved from: www.postserver.at.

Drab-Kurowska, A. (2007). Proces liberalizacji rynku usług pocztowych w świetle regulacji Unii Europejskiej. Zeszyty Naukowe Uniwersytetu Szczecińskiego, Ekonomiczne Problemy Usług, 463, 39-47. 
Envelo lider cyfrowej modernizacji Polski (2017). Puls Biznesu, 7.12.

Jung, P. (2018). Digitalisierung und Briefsubstitution: Erfahrungen in Europa und Schlussfolgerungen fuer Deutschland. WIK Diskussionbeitraege, 436, Oktober.

Kuraszkiewicz R. (2017). Warto wspierać rodzimy biznes. Puls Biznesu, 15.11.

Monitoring Brief- und KEP-Markt (2014). WIK Consult, p. 21.

Niederpruem A. (2018). Hybridpost in Deutschland. WIK, Diskussionsbeitraege, 434, Oktober.

Poczta postawi paczkowe centrum (2017). Puls Biznesu, 19.10.

Skorupska, J. (2017). E-commerce. Strategia - Zarządzanie - Finanse. Warszawa: Wydawnictwo Naukowe PWN.

Sondej, T. (2012). Przewaga konkurencyjna operatorów publicznych na rynku usług pocztowych w Unii Europejskiej. Szczecin: Wydawnictwo Naukowe Uniwersytetu Szczecińskiego.

www.envelo.pl (2018).

Cite this anticle aS: Czaplewski, R. (2018). Basic directions of contemporary postal services markets transformation. European Journal of Service Management, 4 (28/2), 113-119. DOI: 10.18276/ejsm.2018.28/2-13. 